\title{
AKAD SEBAGAI BINGKAI TRANSAKSI BISNIS SYARIAH
}

\author{
Septarina Budiwati \\ Fakultas Hukum \\ Universitas Muhammadiyah Surakarta \\ septarina.budiwati@gmail.com
}

\begin{abstract}
Abstrak
$\mathrm{A}$ kad adalah bingkai transaksi dalam ekonomi syariah, karena melalui akad berbagai kegiatan bisnis dan usaha dapat dijalankan. Akad menfasilitasi setiap orang dalam memenuhi kebutuhan dan kepentingannya yang tidak dapat dipenuhinya tanpa bantuan dan jasa orang lain. Karenanya dapat dibenarkan bila dikatakan bahwa akad merupakan sarana sosial yang ditemukan oleh peradaban umat manusia untuk mendukung kehidupannya sebagai makhluk sosial. Dalam Hukum Islam Istilah "Akad" untuk menyebut perjanjian (overeenkomst) dan bahkan juga untuk menyebut kontrak (contract). Pada pembahasan Fiqih Muamalah kontrak atau perjanjian disebut dengan aqad. Hal itu adalah sebagaimana surat al -Maidah (5) ayat 1 : "Hai orang-orang yang beriman penuhilah akad diantara kamu" ..Karena setiap perjanjian (al-ahdu) pasti akan dimintai pertanggung jawabannya (surat al-Isra (17) ayat 34). Dalam paper ini akan diuraikan tentang apa saja yang menjadi rukun, syarat, prinsip-prinsip serta asas-asas dari akad agar sah dan dapat dijadikan sebagai landasan dalam transaksi-transaksi bisnis berdasarkan syariah.
\end{abstract}

Kata Kunci: Akad, Transaksi, Bisnis Syariah

\begin{abstract}
$A$ kad is framed in Islamic business transactions, because the contract through various business activities and the business can be run. Akad facilitate everyone to meet the needs and interests that can not be fulfilled without the help of others. Therefore justifiable to say that the contract is a means of social invented by human civilization to support life as social creature. Basic contract in Al-Maidah (1) "O ye who believe, fulfill the contract between you" Later in the letter Al-Isra (34) "because any agreement would definitely be held accountable" The paper will describe about what are the pillars, terms, and the principles of the contract to be valid and can be used as a foundation in business transactions based on sharia.
\end{abstract}

Keywords: Contract, Transaction, Islamic Business

\section{Pendahuluan}

Islam adalah agama yang Rahmatan lil 'alamin, yang mempunyai konsep dasar meliputi tiga aspek yakni aqidah, syariah dan akhlak yang mengatur kehidupan manusia secara komprehensif dan universal. Adapun hukum Islam adalah sistem hukum yang bersumber dari ajaran agama Islam yaitu Al -Qur'an dan Hadits. Dikatakan bahwa sifat hukum Islam tidak dapat dilepaskan dengan agama Islam, oleh karenanya dalam mengkaji hukum Islam tidak dapat melepaskan dari pengkajian agama Islam dan pemahaman tentang agama Islam. Kegiatan Ekonomi Syariah merupakan bidang muamalah, akan berhubungan dan mempelajari permasalahan-permasalahan ekonomi masyarakat dari sudut pandang nilai-nilai Islam. ${ }^{1}$

Era globalisasi, kehidupan manusia semakin komplek dan rumit sehingga Allah SWT pastilah sudah mengetahui akan kebutuhan manusia agar selamat hidupnya di dunia dan di

1 Muhammad Ayub, 2009, Understanding Islamic Finance, PT Gramedia Pustaka Utama, Jakarta, Hlm 48. 
akhirat nanti. Ketentuan-ketentuan dalam kitab Al Qur'an telah sempurna, termasuk juga hubungan manusia dengan manusia yang saling membutuhkan.

Sadar atau tidak dampak globalisasi telah dirasakan saat ini. Di era globalisasi ekonomi merupakan bagian yang tak terpisahkan. Globalisasi di bidang ekonomi telah mendorong munculnya perdagangan bebas lintas negara. Perdagangan bebas adalah suatu situasi dimana arus lalu lintas barang, jasa, dan manusia dari dan ke suatu negara di dunia ini tidak mengalami hambatan yang berarti. Secara umum tujuan dalam ekonomi Islam adalah untuk mencapai kesejahteraan bagi masyarakat yang adil dengan menghilangkan bentuk ketidakadilan dan ketidak seimbangan. Terdapat tiga pilar ekonomi syariah, yaitu keadilan, keseimbangan, dan kemaslahatan. Keadilan dalam arti kegiatan perekonomian yang menghindari riba, maisir, gharar, zalim dan haram. Keseimbangan adalah kegiatan invertasi yang dilakukan di sektor riil untuk meningkatkan kesejahteraan masyarakat dengan menekankan kebersamaan dalam memperoleh manfaat (kemaslahatan). ${ }^{2}$

Perjanjian atau Akad mempunyai arti penting dalan kehidupan masyarakat dan merupakan 'dasar dari sekian banyak aktivitas keseharian kita. ${ }^{3}$ Akad adalah bingkai transaksi dalam ekonomi syariah ( M. Isnaeni, 2016), karena melalui Akad berbagai kegiatan bisnis dan usaha dapat dijalankan. Akad menfasilitasi setiap orang dalam memenuhi kebutuhan dan kepentingannya yang tidak dapat dipenuhinya tanpa bantuan dan jasa orang lain. Karenanya dapat dibenarkan bila dikatakan bahwa akad merupakan sarana sosial yang ditemukan oleh peradaban umat manusia untuk mendukung kehidupannya sebagai makhluk sosial. Pernyataan Roscoe Pound dalam abad pertengahan dimana sebagian besar kekayaan orang terdiri dari janji-janji dan keuntungan yang dijanjiakan orang lain terhadapnya. ${ }^{4}$

Dalam Hukum Islam Istilah "Akad" untuk menyebut perjanjian (overeenkomst) dan bahkan juga untuk menyebut kontrak (contract) Istilah akad merupakan istilah tua yang sudah digunakan sejak jaman klasik sehingga sudah sangat baku. ${ }^{5}$ Pada pembahasan Fiqih Muamalah kontrak atau perjanjian disebut dengan aqad. Hal itu adalah sebagaimana surat al-Maidah (5) ayat 1:

“Hai orang-orangyang beriman penuhilah akad diantara kamu”..Karena setiap perjanjian (al-ahdu) pasti akan dimintai pertanggung jawabannya (surat al-Isra (17) ayat 34). Adapun menurut para fuqaha al-aqd adalah perikatan yang ditetapkan melalui ijab qabul berdasarkan ketentuan syara yang menimbulkan akibat hukum terhadap obyeknya. ${ }^{6}$ Permasalahannya sekarang adalah apa saja yang menjadi rukun, syarat, prinsip-prinsip serta asas-asas dari akad agar sah dan dapat dijadikan sebagai landasan dalam transaksi - transaksi syariah.

\section{Pembahasan}

Ketentuan surat al-Maidah ayat (1) yang mewajibkan agar orang-orang yang beriman untuk mematuhi perjanjian yang mereka buat. Dalam hal ini menjelaskan akad sebagai kewajiban yang dibebankan Allah sebagai perintah Allah kepada orang beriman untuk memenuhi kewajibannya yang dibebankan kepada mereka dan kewajiban yang mereka buat kepada sesama manusia sesuai dengan ketentuan agama. ${ }^{7}$

2 Ani Nugraha, 2015, Hukum Perbankan Syariah, Aswaja Pressindo, Yogyakarta, hlm 44

3 Henry R. Cheeseman, Contemporary Business Law, cet-3 (New Jesrsy; Prentice Hall,2000,hlm 187, dalam Syamsul Anwar, 2007,Hukum Perjanjian Syariah, Rajagrafindo Persada, Jakarta, hlm xiii.

4 Pound, Pengantar Filsafat Hukum, alih bahasa Mohammad Radjab (Bhatara Karya Aksara,1982,hlm 144, dalam Syamsul Anwar, Ibid.

5 Syamsul Anwar, 2007, Hukum Perjanjian Syariah, Studi Tentang Akad dalam Fifih Muamalat, Raja Grafindo Perkasa, Jakarta, hal,47

6 Muhammad Syafe'i Antonio ,2001, BANK Syariah dar Teori ke Praktik,Gema Insani Press, Jakarta,Hlm.59 dalam Ani Nugroho, 2015, Hikum Perbankan Syariah, Aswaja Pressindo, Yogyakarta, hlm,85.

7 Ridwan Khirandy, 2013, Hukum Kontrak Indonesia Dalam Perspektif Perbandingan, FH UII Press, hlm 64-65 dalam , Ani Nugraha, ibid,hlm 231 
Akad yang mempunyai makna umum sebagai pertukaran janji diantara dua pihak atau lebih, dan bermakna khusus sebagai komitmen yang menghubungkan penawaran dan penerimaan. ${ }^{8}$ Akad adalah janji atau kontrak, yang bermakna sebagai kewajiban hukum dari salah satu pihak kepada pihak lain yang membuat kontrak. Dengan kontrak yang bersepakat melaksanakan kewajiban hukum yang timbul diantara mereka. ${ }^{9}$

Dalam hukum Islam untuk terbentuknya suatu akad (perjanjian) harus memenuhi rukun dan syarat akad. Syarat akad dibedakan menjadi empat macam yaitu ; (1) syarat terbentuknya akad (syuruth al-in'iqad), (2) syarat keabsahan akad (syuruth ash-shihhah), (3) Syarat berlakunya akibat hukum akad (syuruthan-nafadz) dan (4) syarat mengikatnya akad (syuruth al-luzum). ${ }^{10}$

Dalam hukum Islam, unsur-unsur yang dapat membentuk sesuatu disebut rukun akad adalah unsur-unsur yang membentuk akad, sehingga akad itu terwujud karena adanya unsur-unsur yang membentuknya. Menurut ahli-ahli hukum Islam kontemporer, rukun yang membentuk akad itu ada empat, yaitu ; (1) para pihak yang membuat akad (al-'aqidan), (2) pernyataan kehendak /kesepakatan para pihak (shigatul-aqd), (3) obyek akad (mahallul-'aqd) ,dan (5) tujuan akad (maudhu al-'aqd). Rukun-rukun ini harus ada untuk terjadinya akad.

Salah satu syarat terbentuknya akad adalah terjadinya penyataan kehendak/ kesepakatan (ijab qabul) yang dilakukan oleh kedua belah pihak. Ijab dan Qabul adalah bentuk penawaran dan penerimaan/ persetujuan sebagai pernyataan kehendak untuk tercapainya kesepakatan. Kesepakatan terjadi pada saat ada pertemuan dari dua kehendak yakni penawaran dan penerimaan. Apabila telah diterima atau disetujui oleh pihak lainnya, maka terjadi penerimaan dan terjadi persesuaian kehendak kedua belah pihak. ${ }^{11}$ Dengan tercapainya kesepakatan maka terjadilah akad/ kontrak/perjanian. Kesepakatan dapat dilakukan dengan berbagai cara tertulis, dengan cara lisan maupun dengan simbul-simbul tertentu. Dengan cara tertulis dapat dilakukan dengan membuat akta yang mempunyai kekuatan hukum dalam pembuktian. ${ }^{12}$

Syarat terbentuknya akad (Syurth al-In'iqad); masing-masing rukun (unsur) yang membentuk akad diatas memerlukan syarat-syarat unsur (rukun) itu dapat berfungsi membentuk akad. Tanpa adanya syarat-syarat dimaksud, rukun akad tidak dapat membentuk akad. Dalam syariah ,syarat-syarat dimaksud disebut syarat-syarat terbentuknya akad (Syuruth al-In iqad). Rukun pertama, yaitu para pihak harus memenuhi dua syarat yaitu (1) tamyis, dan (2) berbilang $\left(a t-t a{ }^{\prime} a d d u d\right)$. Rukun kedua yaitu pernyataan kehendak, harus memenuhi dua syarat juga, yaitu (1) adanya persesuaian ijab dan qabul, dengan kata lain adanya kata sepakat, dan (2) kesatuan majelis akad . Rukun ketiga, yaitu obyek akad, harus memenuhi tiga syarat, yaitu (1) obyek itu dapat diserahkan, (2) tertentu, atau dapat ditentukan, dan (3) obyek itu dapat ditransaksikan. Rukum keempat, memerlukan satu syarat, tidak bertentangan dengan syarak. ${ }^{13}$

Rukun-rukun dan syrat-syarat terbentuknya akad yang disebutkan diatas memerlukan kwalitas tambahan sebagai unsur penyempurnaan. Perlu ditegaskan bahwa dengan memenuhi rukun dan syarat-syarat terbentuknya, suatu akad memang sudah terbentuk dan mempunyai wujud yuridis syar'i, namun belum serta merta sah. Untuk sahnya suatu akad, maka rukun dan syarat terbentuknya akad tersebut memerlukan unsur-unsur penyempurnaan yang menjadikan suatu akad sah. Unsur-unsur penyempurnaan ini disebut syarat keabsahan akad. Syarat keabsahan ini dibedakan menjadi dua macam, yaitu syarat keabsahan umum yang berlaku terhadap semua akad dan syarat -syarat syarat-syarat khusus yang berlaku bagi masing-masing aneka akad khusus. ${ }^{14}$

Rukun pertama, yaitu para pihak, dengan dua syarat terbentuknya, yaitu tamyis dan

$8 \quad$ Ibid ,Ridwan Khairandy, hlm 65

9 Ibid, hlm 66

10 Syamsul Anwar, 2007, Hukum Perjanjian Syariah, Studi Tentang Akad dalam Fifih Muamalat ,Raja Grafindo Perkasa, Jakarta, hlm 95

11 Ahmad Miru, 2012, Hukum Kontrak Bernuansa Islam, PT Rajagrafindo Persada, Jakarta,Hlm 27

12 Ibid, hlm 28

13 Syamsul Anwar, op cit, hlm 97

14 Ibid, hlm 99 
berbilang, tidak memerlukan sifat penyempurnaan. Rukun kedua, yaitu pernyataan kehendak dengan kedua syaratnya, juga tidak memerlukan sifat penyempunaan. Namun menurut jumhur ahli hukum Islam syarat kedua dari rukun kedua ini memerlukan penyempurnaan, yaitu persetujuan ijab dan qabul itu harus dicapai secara bebas tanpa paksaan. Bilamana terjadi dengan paksaan, maka akadnya fasid. ${ }^{15}$

Rukun ketiga, yaitu obyek akad, dengan ketiga syaratnya memerlukan penyempurnaan. Syarat 'dapat diserahkan' memerlukan unsur penyempurnaan yaitu bahwa penyerahan itu tidak menimbulkan kerugian (dharar) dan apabila menimbulkan kerugian maka akadnya fasid. Syarat 'obyek harus tertentu' memerlukan kualifikasi penyempurnaan yaitu tidak boleh mengandung gharar, dan apabila mengandung unsur gharar, maka akdnya menjadi fasid. Begitu pula syarat 'obyek harus bisa ditransaksikan' memerlukan unsur penyempurnaan, yaitu harus bebas dari syarat fasid dan bagi akad atas beban harus bebas dari riba. Dengan demikian secara keseluruhan ada empat sebab yang menjadikan fasid suatu akad meskipun telah memenuhi rukun dan syarat terbentuknya, yaitu (1) penyerahan yang menimbulkan kerugian (2) gharar, (3) syarat-syarat fasid, dan (4) riba.Bebas dari keempat faktor ini merupakan syarat keabsahan akad. ${ }^{16}$

Akad yang telah memenuhi rukunnya, syarat terbentuknya dan syarat keabsahannya dinyatakan sebagai akad yang sah. Apabila syarat-syarat keabsahan yang empat ini tidak terpenuhi, meskipun, rukun dan syarat terbentuknya akadtelah dipenuhi, akad tidak sah. Akad ini disebut akad fasid. Menurut ahli-ahli hukum hanafi, akad fasid adalah 'akad yang menurut syarak sah pokoknya, tetapi tidak sah sifatnya' ${ }^{17}$ Maksudnya adalah akad yang telah memenuhi rukun dan syarat terbentuknya, tetapi belum memenuhi syarat keabsahannya. Akad fasid dibedakan dengan akad yang batil kalau akad batil tidak sah baik pokoknya maupun sifatnya dengan kata lain tidak ada wujudnya sama sekali. ${ }^{18}$

Pada asasnya, akad yang telah memenuhi rukunnya, serta syarat-syarat terbentuknya, syarat-syarat keabsahan dan syarat berlakunya maka akad tersebut akan menjadi akad yang sah dan dapat dilaksanakan akibat hukumnya yaitu mengikat kepada para pihak dan tidak boleh salah satu pihak menarik kembali persetujuannya secara sepihak tanpa kesepakatan pihak lain. ${ }^{19}$

Prinsip-prinsip syariah; Hukum Islam, syariah adalah hukum yang berdasarkan ketentuanketentuan di dalam Al-Qur'an dan Sunnah/Hadits untuk mengatur kehidupan manusia berlaku universal dan diterapkan sesuai ruang dan waktu. Menurut Muhammad Yusuf Musa bahwa tiga prinsip dasar hukum Islam adalah tidak mempersulit dan tidak memberatkan, memperhatikan kesejahteraan manusia secara keseluruhan dan mewujudkan keadilan secara menyeluruh. ${ }^{20}$ Menurut Fakhurahman Djamil, terdapat lima prinsip dalam hukum Islam, yakni ${ }^{21}$ meniadakan kepicikan dan tidak memberatkan; menyedikitkan beban; ditetapkan secara bertahap ;memperhatikan manusia; dan mewujudkan keadilan yang merata.

Hukum Islam/ syariah dapat menjamin kesatuan dalam keragaman yaitu penetapann atau penilaian terhadap semua perbuatan dan hubungan manusia sehingga hukum Islam/ Syariah bersifat sistematis yang dapat menghubungkan antara satu dengan yang lainnya. ${ }^{22}$ Artinya bahwa keseluruhan hukum Islam/Syariah dipengaruhi oleh pertimbangan-pertimbangan keagamaan dan etika berupa institusi, transaksi ataupun perjanjian/ akad yang diukur dengan

15 Ibid, hlm 100

16 Ibid, hlm 101

17 Ibn Nurjaim al Mishri, al-asybah wa an-Nazha'ir (Beirut; Dar al Kutub al-Ilmiyah,1985) Hlm.337, dalam Syamsul Anwar, 2007, Hukum Perjanjian Syariah, Studi Tentang Akad dalam Fifih Muamalat, Raja Grafindo Perkasa, Jakarta, Hlm. 101

18 Ibid

19 Syamsul Anwar, 2007, Hukum Perjanjian Syariah, Studi Tentang Akad dalam Fifih Muamalat, Raja Grafindo Perkasa, Jakarta, hlm 95

20 Muhammad Yusuf Musa,1988, Al- Islam wa al-Hajah al- Insaniyyah Ilaih, Terjemahan oleh A.Malik Madani dan Harmin Ilyas 'Islam Suatu Kajian Komprehensif', Jakarta, Rajawali Press, hlm 180, dalam Ani Nugroho, 2015, Hikum Perbankan Syariah, Aswaja Pressindo, Yogyakarta, hlm 40.

21 Fatkhurahman Djamil, 1997, Filsafat Hukum Islam, Logos, Jakarta, hlm 66

22 Josep Schact, 2003, Pengantar Hukum Islam, Islamika, hlm 300 
standar agama dan moral seperti larangan riba, jual beli yang mengandung ketidak pastian (gharar) atau bersikap adil kepada kedua belah pihak. ${ }^{23}$ Menurut Rahmat Djadmika dalam hukum Islam/Syariah prinsip tauhid prinsip yang mendasari seluruh aspek kehidupan. ${ }^{24}$ Tauhid merupakan konsep dasar dan pemahaman menauhidkan atau inti aqidah. MasjfukZuhdi; prinsip hukum Islam ,Tauhid, berkomunikasi langsung dengan Allah SWT, tanpa perantara, menghargai fungsi akal, menyempurnakan iman, menjadikan kewajiban untuk membersihkan jiwa, memperhatikan kepentingan agama dan dunia, persamaan dan keadilan, Amar Makruf nahi mungkar, musyawarah, toleransi, kemerdekaan dan kebebasan, hidup gotong royong. ${ }^{25}$

Sedangkan asas-asas hukum yang digunakan dalam akad/perjanjian antara lain ;

1. Asas Ibahah (Mabda' al-Ibahah), adalah asas umum hukum Islam dalam bidang muamalat secara umum. Asas ini dirumuskan dalam adagium' pada asasnya segala sesuatu itu boleh dilakukan sampai ada dalil yang melarangnya'. Asas ini merupakan kebalikan dari asas yang berlaku dalam masalah ibadah. Dalam hukum Islam, untuk tindakan-tindakan ibadah berlaku asas bahwa bentuk-bentuk ibadah yang sah adalah bentuk-bentuk yang disebutkan dalam dalil-dalil syariah. Orang tidak dapat membuat-buat bentuk baru ibadah yang tidak pernah ditentukan oleh Nabi SAW. Bentuk-bentuk baru ibadah yang dibuat tanpa pernah diajarkan oleh Nabi SAW, itu disebut bid'ah dan tidak sah hukumnya. Sebaliknya dalam tindakan-tingakan mu' amalat berlaku asas sebaliknya, yaitu segala sesuatu itu sah dilakukan sepanjang tidak ada larangan tegas atas tindakan itu. Bila dikaitkan dengan tindakan hukum, khususnya perjanjian/akad ini berarti bahwa tindakan hukum dan perjanjian apa pun dapat saja dibuat sejauh tidak ada larangan khusus mengenai perjanjian tersebut. ${ }^{26}$

2. Asas Kebebasan Berakad (Mabda'Hurriyyah at-Ta'aqud); Hukum Islam mengakui asas kebebasan berakad, yaitu suatu prinsip hukum yang menyatakan bahwa setiap orang bebas membuat akad jenis apapun tanpa terkait kepada nama-nama yang telah ditentukan dalam Undang-undang Syariah dan memasukkan klausul apa saja kedalam akad yang dibuatnya itu sesuai dengan kepentingannya sejauh tidak berakibat makan harta sesama dengan jalan batil. Asas kebebasan berakad ini merupakan konkretisasi lebih jauh dan spesifikasi yang lebih tegas lagi terhadap asas ibahah dalam muamalat. Adanya asas kebebasan berakad dalam hukum Islam didasarkan beberapa dalil antara lain ; (1) Firman Allah "Wahai orang-orang yang beriman, penuhilah akad-akad (perjanjian-perjanjian)" [ Q.S.5:1] , (2) Sabda Nabi SAW, “ Orang-orang muslim itu senantiasa setia kepada syarat-syarat (janji-janji) mereka. ${ }^{27}$ (3) Sabda Nabi SAW : "Barang siapa menjual pohon kurma yang sudah dikawinkan, maka buahnya adalah untuk penjual (tidak ikut terjual), kecuali bila pembeli mensyaratkan lain". ${ }^{28}$ (4) Kaidah Hukum Islam, pada asasnya akad itu adalah kesepakatan para pihak, dan akibat hukumnya adalah apa yang mereka tetapkan atas diri mereka melalui janji. ${ }^{29}$

3. Asas Konsensualisme (Mabda' ar Radha'iyyah) Asas ini menyatakan bahwa untuk terciptanya suatu perjanjian cukup dengan tercapainya kata sepakat antara para pihak tanpa

23 Ibid, hlm 300

24 Rahmat Djadmika,1986, Dasar-Dasar Tata Fikir Tentang Hukum Islam, (Tinjauan Fisafat), Pidato, Pengukuhan IAIN Sunan Ampel, hlm 12 dalam, Ani Nugraha, op cit, hlm 41 25 Masjfuk Zuhdi, 1995, Pengantar Hukum Syariah, Gunung Agung, Jakarta, hlm 21.

26 Syamsul Anwar, 2007, Hukum Perjanjian Syariah, Studi Tentang Akad dalam Fifih Muamalat, Raja Grafindo Perkaa, Jakarta, hlm 84

27 Al-Hakim. Al-Mustadrak (Riyad Maktabah wa Matabi’ an Nasyr al-Haditsah,11) II-49. Hadis ini diriwayatkan oleh al-Hakim dan sahabat Abu Hurairah, dalam Syamsul Anwar, 2007, ibid, hlm 85

28 Al-Bukhari, Sahih al-Bukhari (Ttp : Dar al-Fikr, 1994), III 47, HADIS No 2204, Ibid

29 Asjmuni A Rahman, Qaidah-qaidah Fiqih, Jakarta, Bulan Bintang, 1975, hlm 44, Ibid hlm 85 
perlu dipenuhinya formalitas-formalitas tertentu. Dalam hukum Islam pada umumnya perjanjian-perjanjian itu bersifat konsensual. Para ahli hukum Islam menyimpulkan asas konsensualisme dari dalil-dalil berikut ; (a) Firman Allah ; "Wahai orang-orang yang beriman, janganlah kamu makan harta sesamamu dengan jalan batil, kecuali (jika makan harta sesama itu dilakukan) Dengan tukar-tukar berdasarkan perizinan timbal balik (kata sepakat) diantara kamu” [QS. 4: 29]. (b) Firman Allah : "Kemudian jika mereka menyerahkan kepadamu sebagian dari mas kawin itu atas dasar senang hati (perizinan), konsensus) maka makanlah (ambilah) pemberian itu dengan senang hati sebagai sesuatu baik akibatnya" [QS. 4:4]. (c) Sabda Nabi SAW : Sesungguhnya Jual-beli itu berdasarkan kata sepakat [ Hadis riwayat Ibn Hibban dan Ibn Majah]. (d) Kaidah hukum Islam: Pada asasnya perjanjian/Akad itu adalah kesepakatan para pihak dan akibat hukumnya adalah apa yang apa yang mereka tetapkan melalui janji. ${ }^{30}$

Kutipan ayat pada huruf (a) diatas menunjukkan antara lain bahwa setiap pertukaran secara timbal balik diperbolehkan dan sah selama didasarkan atas kesepakatan. Sedangkan ayat pada huruf (b) menunjukkan bahwa suatu pemberian adalah sah apabila didasarkan kepada perizinan (rela hati) si pemberi.

Hadis Nabi SAW, pada huruf (c) dengan jelas menunjukkan bahwa akad jual beli didasarkan pada perizinan timbal balik (kata sepakat). Meskipun hanya akad jual beli saja yang disebutkan dalam hadis ini, namun untuk akd-akad yang lain diqiyaskan (dianalogikan) kepada akad jual beli, sehingga dengan dasar analogi itu akad-akad lain juga didasarkan kepada kata sepakat.

Kaidah Hukum Islam pada huruf (d) secara amat tegas menyatakan bahwa perjanjian itu pada asasnya adalah kesepakatan para pihak, sehingga bila telah tercapai kata sepakat para pihak, maka tercapailah suatu perjanjian/ akad. ${ }^{31}$

4. Asas Janji Itu Mengikat, didalam al-Qur'an dan Hadis terdapat banyak perintah agar memenuhi janjian. Dalam kaidah usul fikih, "perintah itu pada asasnya menunjukkan wajib" ini berarti bahwa janji itu mengikat dan wajib dipenuhi. Diantara ayat dan hadis dimaksud adalah : (a) Firman Allah, “.........dan penuhilah janji, sesungguhnya janji itu akan dimintai pertanggungjawabannya” [QS,17.34]. (b) Asar dari Ibn Mas'ud, Janji adalah utang. ${ }^{32}$

5. Asas Keseimbangan (Mabda' at-Tawazun fi al-Mu'awadhah): Hukum perjanjian IslaM menekankan tentang adanya keseimbangan para pihak, baik kesimbangan antara apa yang diberikan dengan apa yang diterima maupun keseimbangan dalam memikirkan resiko. Asas keseimbangan dalam transaksi (antara yang diberikan dan yang diterima) tercermin pada dibatalkannya suatu akad yang mengalami ketidak seimbangan prestasi yang mencolok. Asas keseimbangan dalam memikul resiko tercermin terhadap transasksi riba, dimana dalam konsep riba hanya debitur yang memikul segala resiko atas kerugian usaha, sementara kreditur bebas sama sekali dan harus mendapatkan prosentase tertentu sekalipun pada saat dananya mengalami kembalian negatif. ${ }^{33}$

6. Asas Kemaslahatan (Tidak Memberatkan); dengan asas kemaslahatan dimaksudkan bahwa akad yang dibuata oleh para pihak bertujuan untuk mewujudkan kemaslahatan bagi mereka dan tidak boleh menimbulkan kerugian (mudharat) atau keadaan memberatkan (masyaqqah), Apabila dalam pelaksanaan Akad terjadi suatu perubahan keadaan yang tidak dapat diketahui sebelumnya serta membawa kerugian yang fatal bagi pihak bersangkutan sehingga memberatkan, maka kewajibannya dapat diubah dan disesuaikan kepada batas

$30 \quad$ Syamsul Anwar, 2007, Hukum Perjanjian Syariah, Studi Tentang Akad dalam Fifih Muamalat, Raja Grafindo Perkaa, Jakarta, hlm 88

$31 \quad$ Ibid

32 Ibid, hlm 89

33 Ibid,hlm 90 
yang masuk akal. ${ }^{34}$

7. Asas Amanah : dengan asas amanah dimaksudkan bahwa masing-masing pihak berusaha beritikad baik dalam bertransaksi dengan pihak lainnya dan tidak dibenarkan salah satu pihak mengeksploitasi ketidak tahuan mitranya.

8. Asas Keadilan : Keadilan adalah tujuan yang hendak diwujudkan oleh semua hukum. Dalam hukum Islam, keadilan langsung merupakan perintah Al-Qur'an yang menegaskan "Berlaku adillah, karena adil itu lebih dekat kepada taqwa " [ QS; 5:8]. Keadilan merupakan sendi setiap perjanjian yang dibuat oleh para pihak. ${ }^{35}$

\section{Penutup}

Secara umum tujuan dalam ekonomi Islam adalah untuk mencapai kesejahteraan bagi masyarakat yang adil dengan menghilangkan bentuk ketidakadilan dan ketidakseimbangan. Terdapat tiga pilar ekonomi syariah, yaitu keadilan, keseimbangan, dan kemaslahatan. Keadilan dalam arti kegiatan perekonomian yang menghindari riba, maisir, gharar, zalim dan haram.

Akad adalah bingkai transaksi dalam ekonomi syariah, karena melalui Akad berbagai kegiatan bisnis dan usaha dapat dijalankan. Akad menfasilitasi setiap orang dalam memenuhi kebutuhan dan kepentingannya yang tidak dapat dipenuhinya tanpa bantuan dan jasa orang lain. Karenanya dapat dibenarkan bila dikatakan bahwa akad merupakan sarana sosial yang ditemukan oleh peradaban umat manusia untuk mendukung kehidupannya sebagai makhluk sosial.

Akad dengan berlandaskan prinsip-prinsip syariah atau hukum Islam, adalah hukum yang berdasarkan ketentuan-ketentuan di dalam Al-Qur'an dan Sunnah/ Hadits yang mengatur kehidupan manusia secara komprehensif, berlaku universal dan diterapkan sesuai ruang dan waktu.

Hukum Islam/syariah dapat menjamin kesatuan dalam keragaman yaitu penetapann atau penilaian terhadap semua perbuatan dan hubungan manusia sehingga hukum Islam/ Syariah bersifat sistematis yang dapat menghubungkan antara satu dengan yang lainnya. Artinya bahwa keseluruhan hukum Islam/Syariah dipengaruhi oleh pertimbangan-pertimbangan keagamaan dan etika berupa institusi, transaksi ataupun perjanjian/ akad yang diukur dengan standar agama dan moral seperti larangan riba, jual beli yang mengandung ketidak pastian (gharar) atau bersikap adil kepada kedua belah pihak.Dalam hukum Islam/Syariah prinsip tauhid prinsip yang mendasari seluruh aspek kehidupan. Tauhid merupakan konsep dasar dan pemahaman menauhidkan atau inti aqidah.

\section{Daftar Pustaka}

Agus Triyanta,2016, Hukum Perbankkan Syariah, Regulasi, Implementasi dan Formulasi Kepatuhannya Terhadap Prinsip-Prinsip Islam, Setara Press, Malang

Ali, Zainuddin,2008, Hukum Perbankan Syari'ah, Jakarta: Sinar Grafika, 2008

Ani Nugroho, 2015, Hikum Perbankan Syariah, Aswaja Pressindo, Yogyakarta

Budiono Kusumohamijoyo, 2011, Filsafat Hukum, Problematik Ketertiban Yang Adil, Mandar Maju, Bandung

Dewi, Gemala, 2006, Aspek-Aspek Hukum dalam Perbankan Syariah dan Perasuransian Syariah di Indonesia, Kencana, Jakarta

Dewi, Gemala, Hukum Perikatan Islam di Indonesia, Badan Penerbit Fakultas Hukum UI, Jakarta 2005

$34 \quad$ Ibid

35 Ibid, hlm 92 
Ghofur Anshori, Abdul, 2009, Hukum Perbankan Syariah, di Indonesia, R e f 1 i k a Aditama, Yogyakarta

Sudarsono, Heri, Bank dan Lembaga Keuangan Syariah: Deskripsi dan Ilustrasi, Yogyakarta: Ekonisia:, 2003

Masjfuk Zuhdi, 1995, Pengantar Hukum Syariah, Gunung Agung, Jakarta

Susanto, Burhanuddin, Hukum Perbankan Syariah di Indonesia, Yogyakarta : UII Press, 2008

Syamsul Anwar, 2007, Hukum Perjanjian Syariah, Studi Tentang Akad dalam Fifih Muamalat, Raja Grafindo Perkasa, Jakarta 